\title{
Effect of Si and Ni Addition on Graphite Morphology in Heavy-Section Spheroidal Graphite Iron Parts
}

\author{
Branko Bauer ${ }^{1, a}$, Ivana Mihalic Pokopec ${ }^{1, b^{*}}$, Mitja Petrič ${ }^{2, c}$, Primož Mrvar ${ }^{2, d}$ \\ ${ }^{1}$ University of Zagreb, Faculty of Mechanical Engineering and Naval Architecture, Ivana Lucica 5, \\ 10002 Zagreb, Croatia \\ ${ }^{2}$ University of Ljubljana, Faculty of of Natural Sciences and Engineering, Askerceva cesta 12, 1000 \\ Ljubljana, Slovenia \\ abranko.bauer@fsb.hr, bivana.mihalic@fsb.hr, ${ }^{\text {'m }}$ itja.petric@omm.ntf.uni-lj.si, \\ primoz.mrvar@omm.ntf.uni-lj.si
}

Keywords: spheroidal cast iron, heavy-section castings, chunky graphite

\begin{abstract}
Metallographic analysis is applied to the study of the chunky graphite morphology in heavy-section castings of spheroidal graphite cast irons. Three castings with different $\mathrm{Si}$ and Ni contents were prepared. Three positions in casting from the edge to the centre, with different cooling rates, were chosen for microstructure observation. The effect of the Si and Ni content on the graphite morphology and mechanical properties of heavy-section spheroidal graphite cast iron parts was investigated. Cerium containing commercial inoculant was used for in-stream inoculation. Chunky graphite area was estimated in micro- and macrostructure. Mechanical properties were determined on tensile test bars taken from the centre of the casting. Macro- and microstructure examination showed that the castings with high Si-content and Ni addition had chunky graphite present, while the castings produced by use of low Si and Ni containing charge had no chunky graphite. High Si-content is strong chunky graphite promoter, especially in castings with slow cooling rate. Ni addition also promotes chunky graphite formation, but only in thermal centre of the casting (where the cooling rate is the lowest). The elongation is severely lowered when chunky graphite appears in the microstructure.
\end{abstract}

\section{Introduction}

Spheroidal graphite cast iron is important construction material within cast iron family. Production of heavy-section spheroidal graphite cast iron castings is increasing in windmill industry, heavy automotive industry and spent-nuclear-fuel containers industry. Future applications will require even larger wall-thicknesses. The demand for good mechanical properties will be even more pronounced in these castings. Spherical morphology of the precipitated graphite is the most important factor to achieve required mechanical properties. [1-6]

Heavy-sectioned parts are characterised by low cooling rate and long solidification time. As a consequence decrease in nodule count, increase in nodule size and occurrence of graphite degeneration occur, what leads to decrease of mechanical properties. [3-7]

The most deleterious graphite degeneration is chunky graphite, CHG. CHG eutectic cells are a network of highly branched and interconnected strings of graphite growing along the "c" direction. CHG decreases tensile strength, elongation and fatigue strength. Conditions favouring $\mathrm{CHG}$ formation are: low cooling rate, high $\mathrm{CE}$, high $\mathrm{Ce}, \mathrm{Ca}, \mathrm{Si}$, Ni content, macro- and microsegregations (trace elements) and production factors (inoculation, pouring temperature). [3-7]

Silicon has been linked to formation of chunky graphite since 1970s [8]. With increasing Si-level the risk for chunky graphite increases with decreasing cooling rate. With higher Si-level in the iron faster cooling rate is required to provide a CHG free casting. In Fig. 1, the two lines indicated refer to different trace element levels or metal processing history (different charges and different melt treatments). Solid curve was proposed by Prince et al. in 1991 [9] and dotted curve by Jiyang Zhou et al. in 1987. [10] 


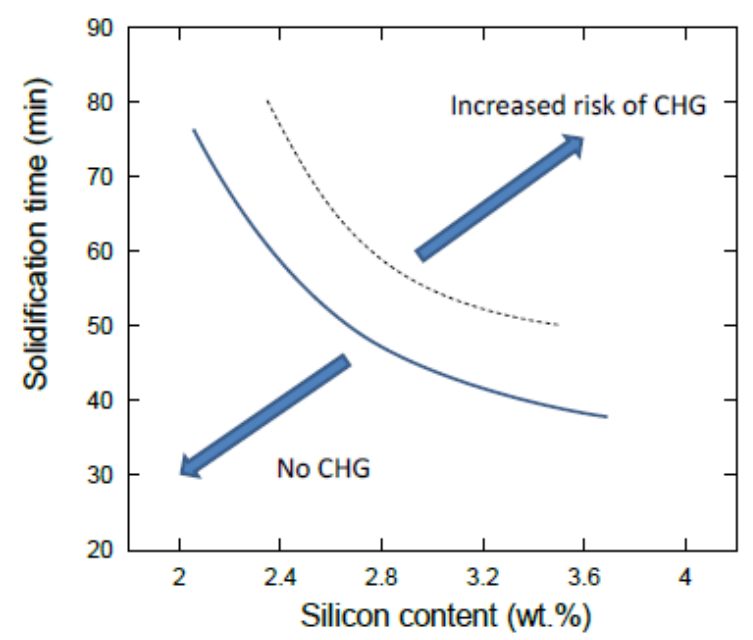

Figure 1. Influence of solidification time and Si content on the formation of CHG. Solid curve [9], dotted curve [10].

Nickel is reported to both, increase and decrease of CHG formation $[2,3,5,6]$. Behaviour of Ni may be related to Ni content in the iron and the melt treatment method. According to Löblich [3], the effect of nickel is so strong that in austenitic ductile iron chunky graphite already occurs in thin section.

Low cooling rate favours the formation of chunky graphite. Low cooling rate may also promote abundant gathering of the low-melting point elements in the channel decreasing the melting point of the liquid iron. The channel remains a little longer liquid and the slowly enveloping and nonenveloping austenite shell occur, leading to CHG formation, Table 1.

Table 1. Relationship between the type of austenite shell and graphite shape [10].

\begin{tabular}{|c|c|c|}
\hline Austenite shell & Graphite formation process & Graphite shape \\
\hline (1) Fast enveloping & 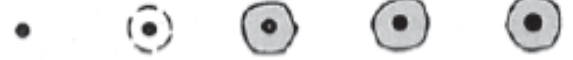 & - \\
\hline (2) Slow enveloping & - & \\
\hline (3) No enveloping & - (0) & \\
\hline
\end{tabular}

\section{Experimental Methods}

The influence of high silicon content and nickel addition on graphite morphology and mechanical properties of heavy-section spheroidal graphite cast iron at different cooling rates were studied. Three conical blocks $\Phi 300 \times 350 \mathrm{~mm}$ were casted, Fig. 2 . KALPUR ${ }^{\circledR}$ direct pouring process through the feeder was used. Sodium silicate $/ \mathrm{CO}_{2}$ process was used for moulding. Three different test melts were prepared in medium frequency induction furnace: EN-GJS-400-15, EN-GJS-400-15 with 3.5 wt. $\% \mathrm{Si}$ and EN-GJS-400-18 with 0.7 wt. \% Ni. The charge material composition is listed in Table 2. Sandwich treatment of base melt at $1480^{\circ} \mathrm{C}$ with 1.8 wt.\% FeSiMg and 0.2 wt.\% cover alloy was carried out, Table 3. To raise $\mathrm{Si}, 0.7 \mathrm{wt} . \% \mathrm{FeSi}$ was aded in the ladle for spheroidising treatment or $0.7 \mathrm{wt} . \% \mathrm{Ni}$ to raise $\mathrm{Ni}$ content. $0.45 \mathrm{wt} . \%$ of Ce based commercial inoculant was used for in-stream inoculation, Table 4. Pouring temperature was approximately $1400^{\circ} \mathrm{C}$ and pouring time 25 s. Filling and solidification simulation was done with ProCAST software. 

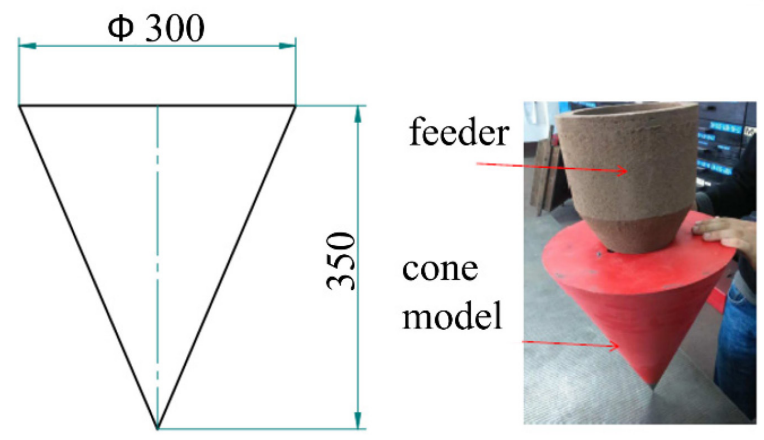

Figure 2. Cone pattern and feeder.

Table 2. Charge materials used for melting.

\begin{tabular}{|c|c|c|c|c|c|}
\hline Total & $\begin{array}{c}\text { Sorelmetal }^{\circledR} \\
{[\text { wt. \%] }}\end{array}$ & $\begin{array}{c}\text { Returns } \\
{[\text { wt. \%] }}\end{array}$ & $\begin{array}{c}\text { Steel scrap } \\
{[\text { wt. \%] }}\end{array}$ & $\begin{array}{c}\text { SiC } \\
{[\text { wt. \%] }}\end{array}$ & $\begin{array}{c}\text { FeSi } \\
{[\text { wt. \%] }}\end{array}$ \\
\hline $5.6 \mathrm{t}$ & 70 & 21 & 9 & 0.1 & $0.2 *$ \\
\hline
\end{tabular}

Table 3. Chemical composition of nodularizer and cover alloy.

\begin{tabular}{|c|c|c|c|c|c|c|c|}
\hline \multirow{2}{*}{ Alloy } & \multicolumn{7}{|c|}{ Chemical composition [wt. \%] } \\
\cline { 2 - 8 } & $\mathrm{Si}$ & $\mathrm{Mg}$ & $\mathrm{Ba}$ & $\mathrm{Ca}$ & $\mathrm{Al}$ & $\mathrm{RE}$ & $\mathrm{Fe}$ \\
\hline nodularizer & $44-48$ & $3.5-3.8$ & - & $0.9-1.1$ & $0.5-1.2$ & $0.6-0.8$ & Bal. \\
\hline cover alloy & $46-50$ & - & $1.8-2.2$ & $0.4-0.6$ & $0.5-1.0$ & - & Bal. \\
\hline
\end{tabular}

Table 4. Chemical composition of inoculant.

\begin{tabular}{|c|c|c|c|c|}
\hline \multicolumn{5}{|c|}{ Chemical composition [wt. \%] } \\
\hline $\mathbf{S i}$ & $\mathbf{C e}$ & $\mathbf{A l}$ & $\mathbf{O} \mathbf{~ i ~}$ & $\mathbf{F e}$ \\
\hline $70-76$ & $1.5-2.0$ & $0.75-1.25$ & $>1$ & Bal. \\
\hline
\end{tabular}

\section{Results and Discussion}

Just before pouring the melt in the mould, the chilled coupon was analysed by optical emission spectrometer, ARL 3460. Chemical composition is listed in Table 5. Active Carbon Equivalent Liquidus, ACEL was determined using Adaptive Thermal Analysis System - ATAS ${ }^{\circledR}$.

Table 5. Chemical composition of the melts.

\begin{tabular}{|c|c|c|c|c|c|c|c|c|c|c|c|c|c|c|c|}
\hline \multirow{2}{*}{ Cone No. } & \multicolumn{15}{|c|}{ Mass fraction [wt. \%] } \\
\hline & C & $\mathbf{S i}$ & Mn & $\mathbf{S}$ & $\mathbf{P}$ & Mg & Co & $\mathbf{N i}$ & $\mathrm{Cr}$ & $\mathbf{C u}$ & Sn & Mo & $\mathbf{T i}$ & Al & ACEL ${ }^{*}$ \\
\hline 1 & 3.66 & 2.15 & 0.169 & 0.010 & 0.029 & 0.034 & 0.016 & 0.027 & 0.027 & 0.020 & 0.004 & 0.003 & 0.007 & 0.0131 & 4.12 \\
\hline 2 & 2.91 & 3.46 & 0.162 & 0.006 & 0.034 & 0.059 & 0.016 & 0.026 & 0.030 & 0.016 & 0.006 & 0.003 & 0.011 & 0.0247 & 4.24 \\
\hline 3 & 3.25 & 1.75 & 0.160 & 0.011 & 0.032 & 0.036 & 0.017 & 0.720 & 0.030 & 0.016 & 0.004 & 0.003 & 0.007 & 0.0095 & 4.17 \\
\hline
\end{tabular}

Cooling rates at different positions in the cone block were determined from solidification simulation in a liquid state between pouring temperature and nucleation temperature. Three different positions in the casting $(\mathrm{S} 1, \mathrm{~S} 2, \mathrm{~S} 3)$ with three different cooling rates $\left(0.036 ; 0.022 ; 0.016{ }^{\circ} \mathrm{C} / \mathrm{s}\right)$ were chosen $50 \mathrm{~mm}$ below the cone base for microstructure analysis, Fig. 3. Dimensions of samples were $25 \times 25 \times 10 \mathrm{~mm}$. 

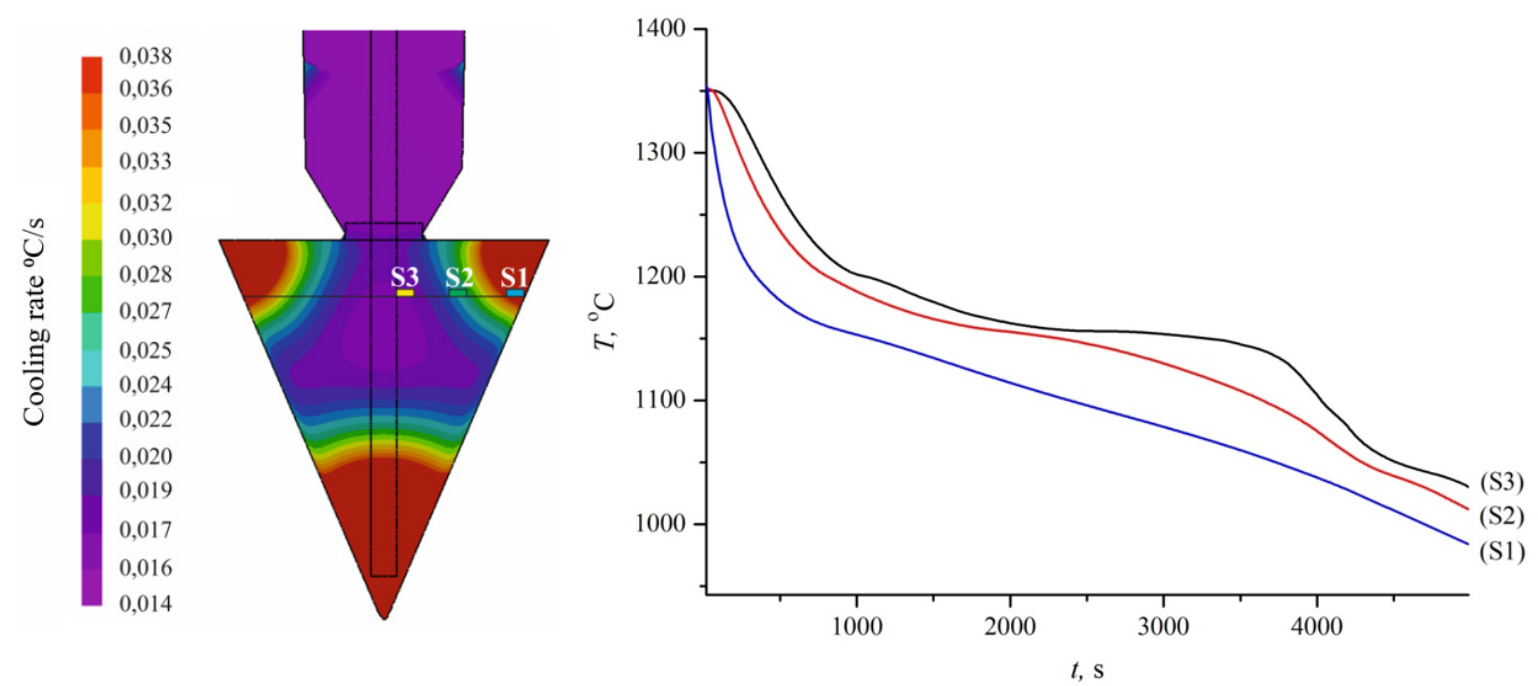

Figure 3. Cooling rates in the cone block and simulated cooling curves of the selected positions for microstructure analysis.

Macroanalysis for visual examination of $\mathrm{CHG}$ appereance was done on cross-sections of the cone blocks, Fig. 4. CHG area was estimated on macrographs with AnalySIS ${ }^{\circledR} 5.0$ software. Area affected by $\mathrm{CHG}$ in cone 1 was $0 \%$, in cone $2,63 \%$ and in cone $3,13 \%$. Higher Ni content caused $\mathrm{CHG}$ formation in thermal center of the casting below the feeder, while CHG in casting with higher Si content was irregularly distributed over the entire section except on the top of the cone. The highest concentration of $\mathrm{CHG}$ in cone 2 was also in center of the casting, where cooling rate was lowest. On cone 2 , slow cooling austenite dendrites can be clearly seen along the edge of the lateral sides. They are weakly branched, and their basic arrangement is perpendicular to the mould wall, bending upwards in the direction of the heat flow. They occur often during solidification of thickwalled castings because of low cooling rate, especially when Si content in spheroidal graphite cast iron is higher [11]. Influence of $\mathrm{Si}$ and $\mathrm{Ni}$ on $\mathrm{CHG}$ formation is in accordance with literature [6]. The irregular distribution of CHG on the cross-section of the casting is consistent with [12]. In [12], CHG appeared in the casting center only when there was a little amount. Greater amount of CHG was irregularly distributed over the entire cross-section.

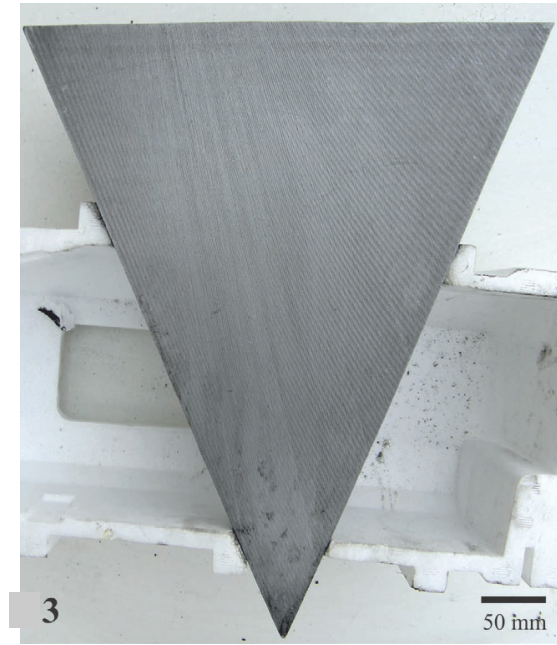

Cone 1

EN-GJS-400-15

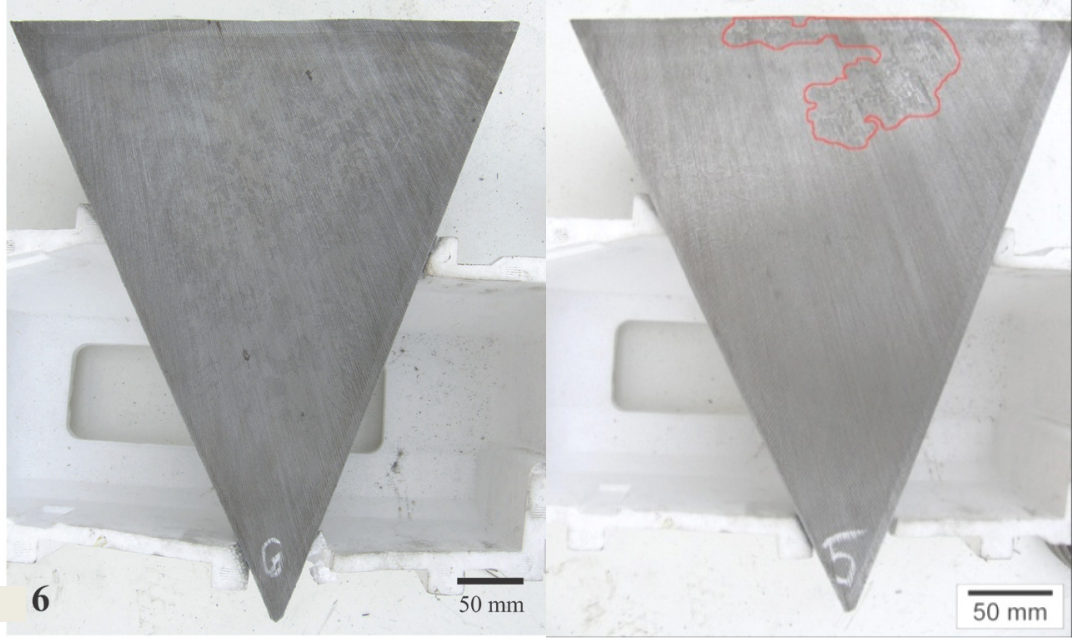

Cone 2

Cone 3

EN-GJS-400-15 with 3.5 wt.\% Si EN-GJS-400-18 with 0.7 wt.\% Ni

Figure 4. Cross-sections of cone blocks. 
Microstructure of cones 1, 2 and 3 is shown in Fig. 5, 6 and 7. On sample S1 of cone 1, 1-S1, with highest cooling rate graphite nodules with good nodularity are dominant. They are equally distributed in the metal matrix, with some degenerate nodules of smaller dimensions, Fig. 5. With lower cooling rate graphite particles are smaller and nodularity deterioration occurs, sample 1-S2. There are very few regular nodules and their dimensions are considerably smaller than the nodules in the sample 1-S1. With a further reduction in the cooling rate, the dimensions of nodules do not change and the number of regular nodules is reduced, sample 1-S3. The degenerate forms of graphite prevail, and the proper nodules are almost gone.

High Si content negatively influences the shape of graphite and nodularity, Fig. 6. Si is a strong promotor of $\mathrm{CHG}$ in thick-walled castings [3,5,7,13], what can be seen also in this investigation. CHG occured in great amount. Area affected by CHG increases as the cooling rate decreases. Around the area with chunky graphite there are proper graphite nodules. The area with chunky graphite is clearly separated from the surrounding area with a nodular structure. Chunky graphite appears most often in the form of eutectic cells or rarely in intercellular form of different dimensions (sample 2-S1), Fig. 6. CHG inside cells appears in form of fine graphite particles - fine $\mathrm{CHG}$. In boundary region of $\mathrm{CHG}$ cells graphite particles are significantly bigger and coarser coarse CHG, Fig. 8.

High Ni content significantly improved the shape of graphite and nodularity, Fig. 7. Nodularity is significantly higher in comparison with cone 2 (EN-GJS-400-15 with 3.5 wt. \% Si), Fig. 6. Influence of $\mathrm{Ni}$ on the appearance of $\mathrm{CHG}$ is considerably lower than the effect of $\mathrm{Si}$, so $\mathrm{CHG}$ appeared more towards center of the casting, samples 3-S2 and 3-S3, Fig. 7. Nodules are equally distributed in a metal matrix with a high degree of nodularity. An extremely small proportion of degenerate graphite was observed. Reducing the cooling rate caused an increase in the nodule size. In this melt with high Ni content, Si content was quite low which could have the effect of reducing CHG appearance despite high Ni content.

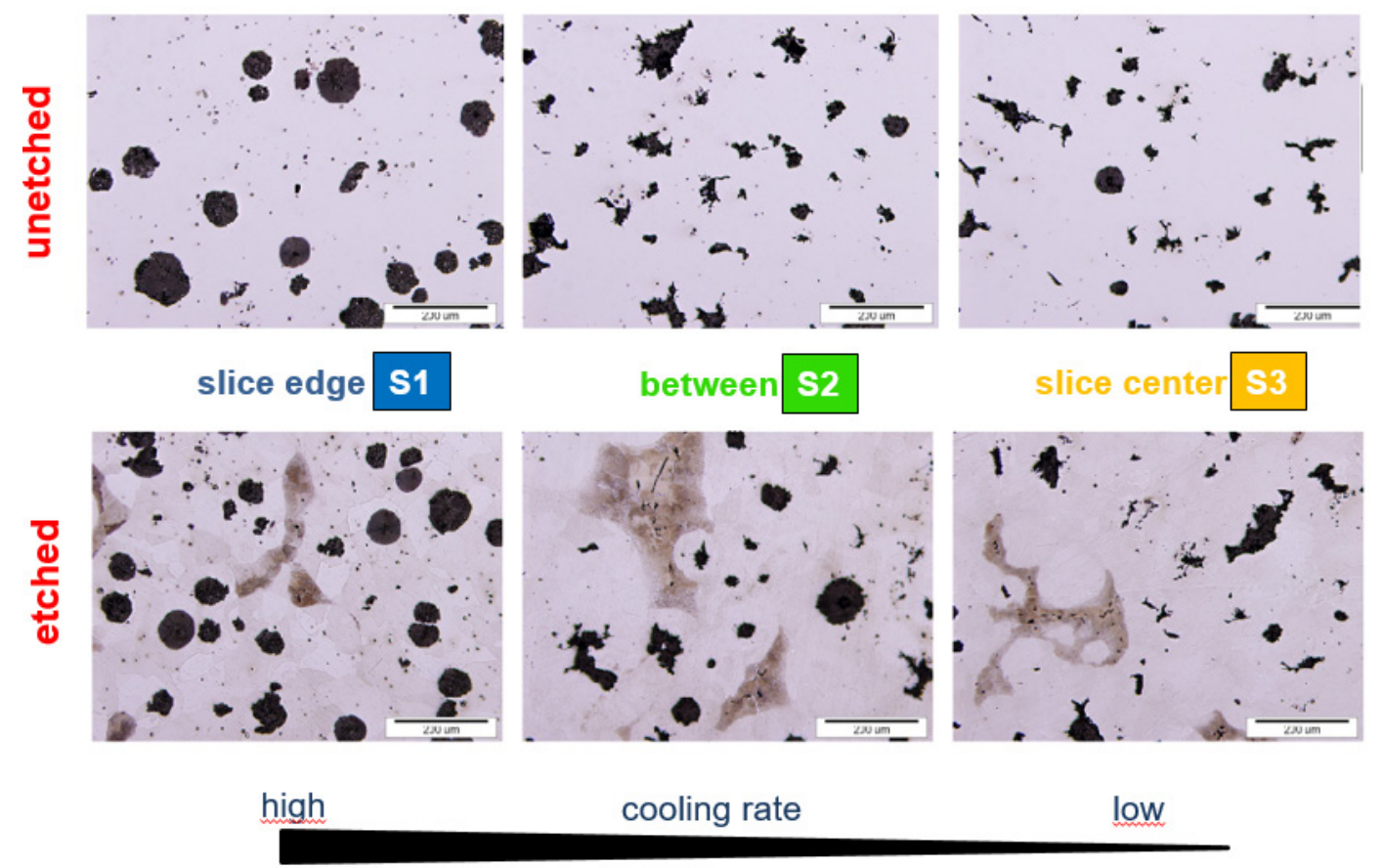

Figure 5. Microstructure of cone 1, EN-GJS-400-15. 


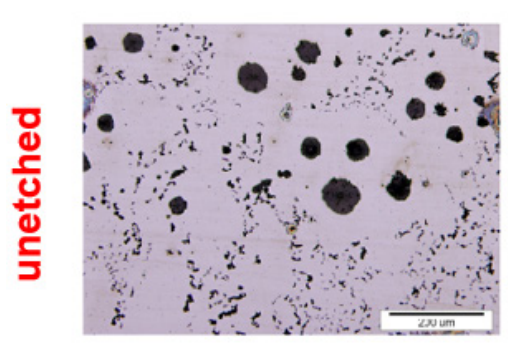

slice edge $\mathbf{S 1}$

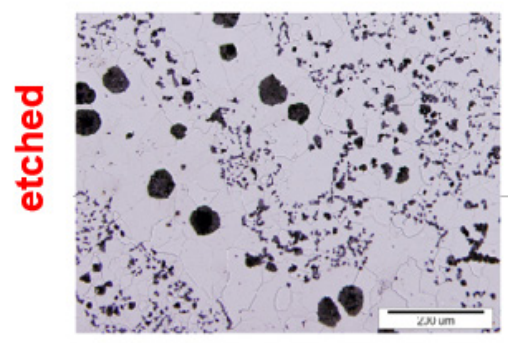

high

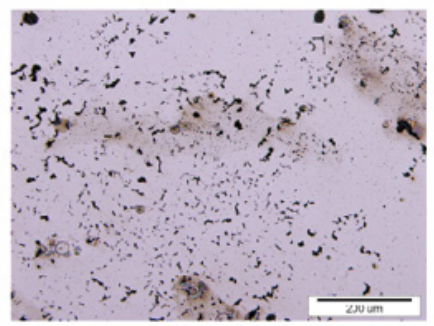

between $\mathbf{S 2}$

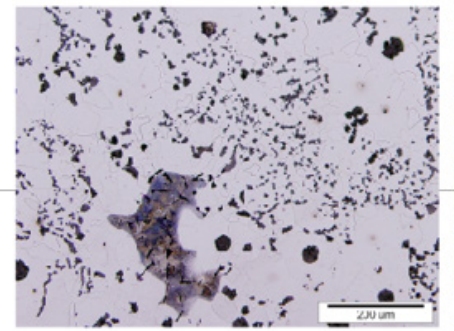

cooling rate

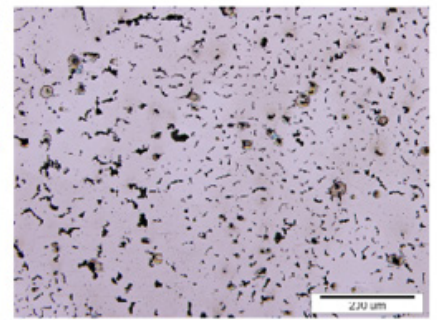

slice center $\$ 3$

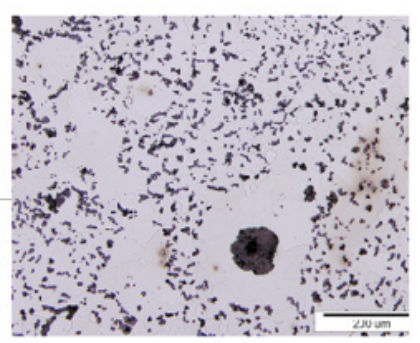

low

Figure 6. Microstructure of cone 2, EN-GJS-400-15 with 3.5 wt. \% Si.
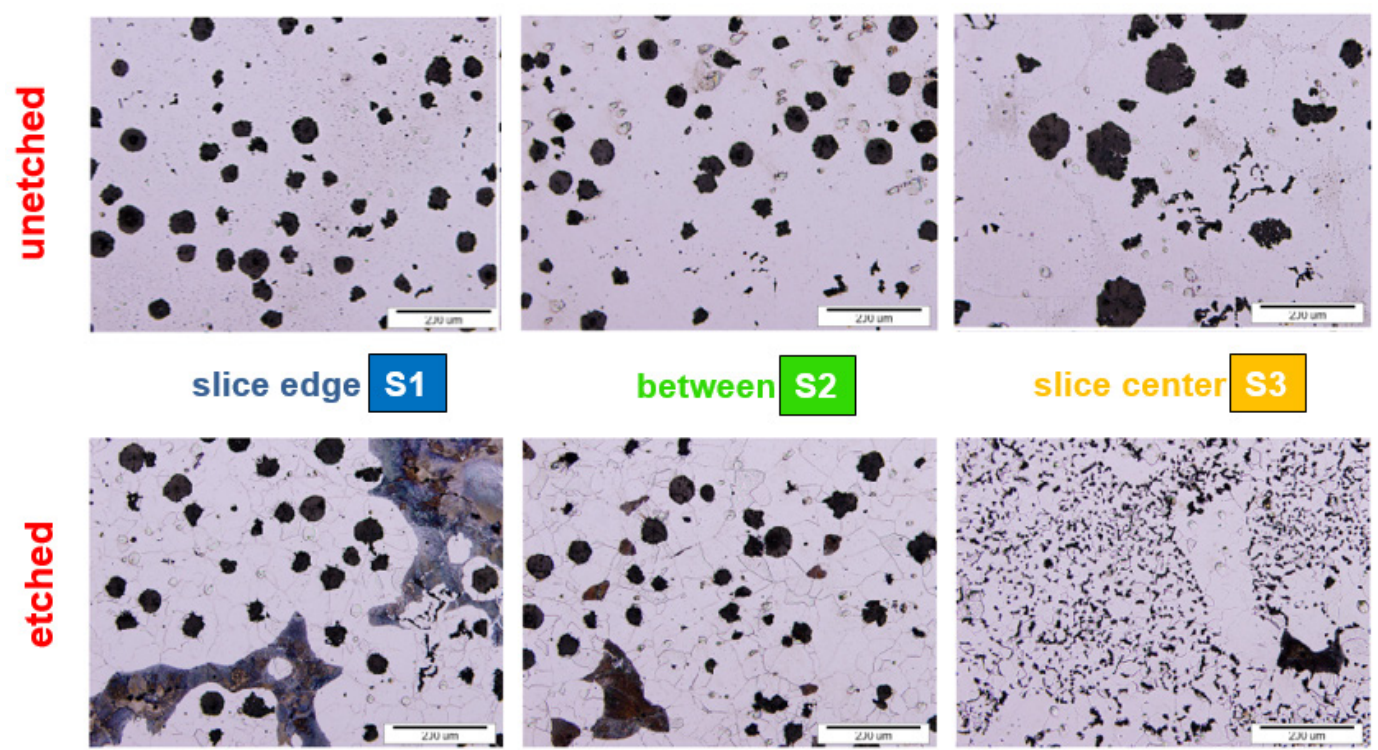

between $\mathrm{S2}$
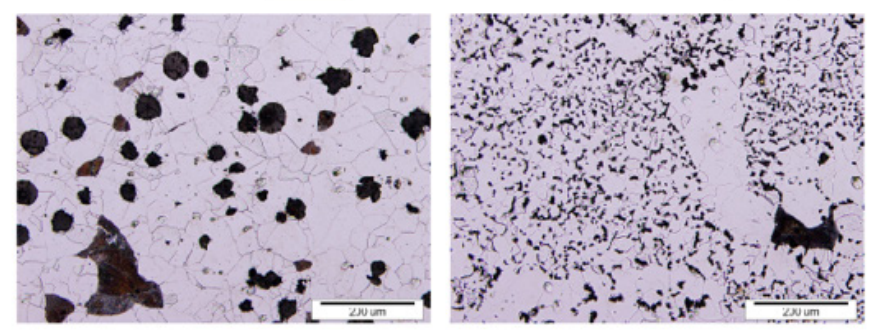

high

cooling rate

low

Figure 7. Microstructure of cone 3, EN-GJS-400-18 with 0.7 wt.\% Ni.

The results of metallographic analysis of graphite shape for three different cooling rates are shown in Table 6. Negative influence of cooling rate reduction on graphite morphology and primarily nodularity could be noticed. The nodularity in all samples is generally low. The values range from about $40 \%$ to $70 \%$. This means that none of the samples has a satisfactory nodularity value to meet the requirements according to EN 1563: 2012-03. Nodularity must be $80 \%$ or more to achieve the required mechanical properties. 


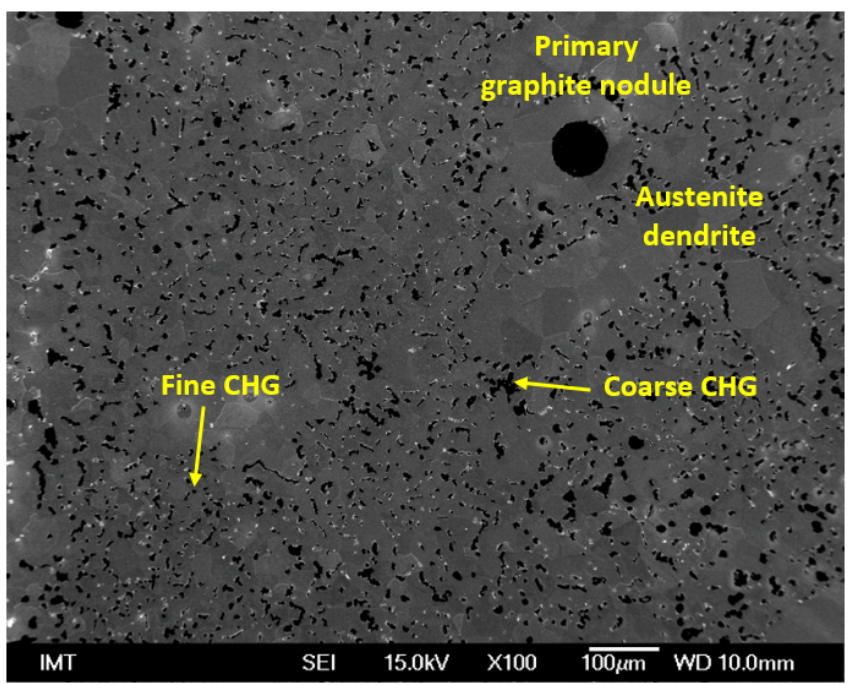

Figure 8. CHG area in cone 2, EN-GJS-400-15 with 3.5 wt. \% Si, sample 2-S2.

The lowest values of nodularity were determined in samples in which the degenerate forms of graphite prevailed with only a few regular nodules. The area fraction of graphite ranges between $5 \%$ and $13 \%$ and is proportional to the cooling rate at cone 1 and 3, while at cone 2 with higher content of $\mathrm{Si}$ is inversely proportional. Area fraction of graphite of some samples is below $9 \%$ what is quite a low value.

Table 6. Results of metallographic analysis of graphite shape and metal matrix.

\begin{tabular}{|c|c|c|c|c|c|c|}
\hline $\begin{array}{c}\text { CONE- } \\
\text { SAMPLE }\end{array}$ & Shape & Size & $\begin{array}{c}\text { Nodularity } \\
{[\%]}\end{array}$ & $\begin{array}{c}\text { Area frac. of } \\
\text { graphite [\%] }\end{array}$ & $\begin{array}{c}\text { Ferrite } \\
{[\%]}\end{array}$ & $\begin{array}{c}\text { Pearlite } \\
{[\%]}\end{array}$ \\
\hline 1-S1 & VI & 5 & 68.8 & 13.3 & 71.3 & 28.7 \\
\hline 1-S2 & IV,II(45\%) & 5 & 46.5 & 7.9 & 73.8 & 26.2 \\
\hline 1-S3 & IV,II(30\%) & 5 & 42.9 & 5.2 & 88.0 & 12.0 \\
\hline 2-S1 & VI,III(40\%) & 7 & 45.3 & 7.1 & 84.5 & 15.5 \\
\hline 2-S2 & V,III(45\%) & 6 & 41.2 & 8.3 & 80.3 & 19.7 \\
\hline 2-S3 & V,II(40\%) & 7 & 42.5 & 9.0 & 83.7 & 16.3 \\
\hline 3-S1 & VI & 5 & 66.2 & 10.9 & 81.6 & 18.4 \\
\hline 3-S2 & VI & 6 & 66.1 & 8.7 & 84.9 & 15.1 \\
\hline 3-S3 & VI & 6 & 69.4 & 9.1 & 81.9 & 18.1 \\
\hline
\end{tabular}

Based on the results in Table 6., it can be seen that the metal matrix consists of ferrite and perlite with amounts of ferrite of approximately 70 to $90 \%$. Lower values of ferrite were observed in cone 1, except for the sample 1-S3 in which the highest ferrite fraction was observed. The presence of carbides in the microstructure was not observed. The cooling rate does not affect the proportion of ferrite and pearlite in the structure.

Three samples for the tensile test were taken from the center of the cone base in the area 0 to $50 \mathrm{~mm}$ from the cone base below the feeder. The mean values are shown in Table 7., $\mathrm{R}_{\mathrm{m}}, \mathrm{R}_{\mathrm{p} 0.2}$ and $\mathrm{A}_{5}$. Tensile strength value in cone 2 is lower than the minimum required value for thick-walled castings in the standard $370 \mathrm{~N} / \mathrm{mm}^{2}$. Yield strength value in cone 1 is lower than the minimum required $240 \mathrm{~N} / \mathrm{mm}^{2}$. The elongation at rupture is severely lowered when chunky graphite appears in the microstructure, cone 2 and 3. In general, lower mechanical properties are the result of the reduction of the cooling rate in thermal center of the casting.

Table 7. Mechanical properties in thermal center of cones.

\begin{tabular}{|c|c|c|c|}
\hline CONE & $\mathrm{R}_{\mathrm{m}}\left[\mathrm{N} / \mathrm{mm}^{2}\right]$ & $\mathrm{R}_{\mathrm{p} 0.2}\left[\mathrm{~N} / \mathrm{mm}^{2}\right]$ & $\mathrm{A}_{5}[\%]$ \\
\hline 1 & 388 & 226 & 10.6 \\
\hline 2 & 364 & 274 & 1.2 \\
\hline 3 & 466 & 368 & 3.4 \\
\hline
\end{tabular}




\section{Conclusion}

Macro- and microstructure examination showed that the castings with high Si-content and $\mathrm{Ni}$ addition had chunky graphite present, while the castings produced by use of low $\mathrm{Si}$ and $\mathrm{Ni}$ containing charge had no chunky graphite. High Si-content is strong chunky graphite promoter, especially in castings with slow cooling rate. Ni addition also promotes chunky graphite formation, but only in thermal center of the casting, where the cooling rate is the lowest. Tensile test performed on test bars showed that non of the examined samples met the requirements for mechanical properties according to the standard. The elongation is severely lowered when chunky graphite appears in the microstructure.

\section{Acknowledgements}

This work is partially supported by the foundry MIV d.d. Varaždin.

\section{References}

[1] S. Liang, G. Erjun, T. Changlong, Effect of Bi on graphite morphology and mechanical properties of heavy section ductile cast iron, China Foundry. 11 (2014) 125-131.

[2] R. Källbom, K. Hamberg, M. Wessen, L.E. Björkegren, On the solidification sequence of ductile iron castings containing chunky graphite, Mat. Sci. Eng. A-Struct. 413-414 (2005) 346-351.

[3] H. Löblich, Effect of nucleation conditions on the development of chunky graphite in heavy ductile iron castings, Giessereiforschung. 58 (2006) 28-41.

[4] P. Ferro, A. Fabrizi, R. Cervo, C. Carollo, Effect of inoculant containing rare earth metals and bismuth on microstructure and mechanical properties of heavy-section near-eutectic ductile iron castings, J. Mater. Process. Tech. 213 (2013) 1601-1608.

[5] R. Källbom, K. Hamberg, L. E. Björkegren, Chunky Graphite - Formation and Influence on Mechanical Properties in Ductile Cast Iron, in: J. Samuelsson, G. Marquis, J. Solin (Eds.), Proceedings of the Gjutdesign 2005, Espoo, Finland, 2005, pp. 63-86.

[6] K. Hartung, O. Knustad, K. Wardenaer, Chunky graphite in ductile cast iron castings- Theories and examples, Indian Foundry Journal. 55 (2009) 25-29.

[7] J. Lacaze, L. Magnusson, J. Sertucha, Review of microstructural features of chunky graphite in ductile cast irons, in: 2013 Keith Millis Symp. on Ductile Cast Iron, AFS, Nashville, USA, 2013, pp. 360-368.

[8] S. I. Karsay, E. Campomanes, Control of graphite structure in heavy ductile iron castings, AFS Transactions, 78 (1970) 85-92.

[9] B. Prinz, K. J. Reifferscheid, T. Schulze, R. Döpp, E. Schürman, Untersuchung von Ursachen von Graphitentartungen bei Gusseisen mit Kugelgraphit in Form von Chunky-Graphit, Giessereiforschung. 43 (1991) 107-115.

[10] J. Zhou, W. Schmitz, S. Engler, Untersuchung der Gefügebildung von Gußeisen mit Kugelgraphit bei langsamer Erstarrung, Giessereiforschung. 39 (1987) 55-70.

[11] J. Zhou, Colour Metallography of Cast Iron, Spheroidal graphite Cast Iron, Part II, China Foundry. 7 (2010) 183-198.

[12] I. Asenjo, P. Larranaga, J. Sertucha, R. Suarez, J.-M. Gomez I. Ferrer, J. Lacaze, Effect of mould inoculation on formation of chunky graphite in heavy section spheroidal graphite cast iron parts, Int. J. Cast. Metal. Res. 20 (2007) 319-324.

[13] S. I. Karsay, Ductile Iron: Production Practices, American Foundry Society, 1985. 